\title{
Complications Are Not Increased With Acetabular Revision of Metal-on-metal Total Hip Arthroplasty
}

\author{
Colin T. Penrose BS, Thorsten M. Seyler MD, PhD, Samuel S. Wellman MD, \\ Michael P. Bolognesi MD, Paul F. Lachiewicz MD
}

Published online: 17 March 2016

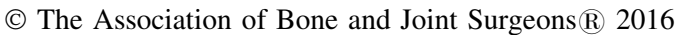

\begin{abstract}
Background Isolated revision of the acetabular component in the setting of total hip arthroplasty has an increased risk of dislocation. With local soft tissue destruction frequently associated with failed metal-on-metal (MoM) bearings, it is presumed that acetabular revision of these hips will have even greater risk of complications. However, no study directly compares the complications of MoM with metal-on-polyethylene (MoP) acetabular revisions.

Questions/purposes In the context of a large database analysis, we asked the following questions: (1) Are there

One of the authors (MPB) received funding from DePuy Johnson and Johnson (West Chester, PA, USA) outside the submitted work. One of the authors (SSW) received grants and other from Stryker (Kalamazoo, MI, USA), grants and other from Biomet (Warsaw, IN, USA), grants and other from Zimmer (Warsaw, IN, USA), grants and other from DePuy Johnson and Johnson, and personal fees from Total Joint Orthopedics (Salt Lake City, UT, USA) outside the submitted work. One of the authors (PFL) received other from The Hip Society, other from OST Society, Inc, other from $J$ Arthroplasty, other from JSOA, personal fees from Innomed (Savannah, GA, USA), personal fees from Mallinckrodt (St Louis, MO, USA), personal fees from Gerson Lehrman Group (New York, NY, USA), personal fees from Guidepoint Global Advisors, and grants from Zimmer outside the submitted work. One of the authors (TMS) received other from Total Joint Orthopedics, Inc, outside the submitted work.

All ICMJE Conflict of Interest Forms for authors and Clinical Orthopaedics and Related Research ${ }^{\circledR}$ editors and board members are on file with the publication and can be viewed on request. Each author certifies that his or her institution approved or waived approval for the human protocol for this investigation and that all investigations were conducted in conformity with ethical principles of research
\end{abstract}

C. T. Penrose, T. M. Seyler, S. S. Wellman, M. P. Bolognesi, P. F. Lachiewicz $(\bowtie)$

Department of Orthopaedic Surgery, Duke University Medical Center, 2301 Erwin Road, Durham, NC 27710, USA

e-mail: Paul.lachiewicz@gmail.com differences in early medical or wound complications after isolated acetabular revision of MoM and MoP bearing surfaces? (2) Are there differences in the frequency of dislocation, deep infection, and rerevision based on the bearing surface of the original implant?

Methods A review of the 100\% Medicare database from 2005 to 2012 was performed using International Classification of Diseases, 9th Revision and Current Procedural Terminology codes. We identified 451 patients with a MoM bearing and 628 patients with a MoP bearing who had an isolated acetabular revision and a minimum followup of 2 years. The incidence, odds ratios, and 95\% confidence intervals for early medical or wound complications were calculated using a univariate analysis at 30 days with patient sex and age group-adjusted analysis for blood transfusion. The incidence, odds ratio, and 95\% confidence intervals for dislocation, deep infection, and rerevision were calculated using a univariate analysis at 30 day, 90 days, 1 year, and 2 years using a subgroup analysis with the Cochran-Mantel-Haenszel test to adjust for patient gender and age groups.

Results There were no differences between the MoM and MoP isolated acetabular revisions in the incidence of 30day local complications. There was a greater risk of transfusion in the MoP group than the MoM group (134 of 451 [30\%] versus 230 of 628 [37\%]; odds ratio [OR], $0.731 ; 95 \%$ confidence interval $[\mathrm{CI}], 0.565-0.948 ; \mathrm{p}=$ 0.018 ). There were no differences at 2 years between the MoM and MoP acetabular revisions in the incidence of dislocation, infection, or rerevision. When analyzed by patient sex and age group, there were more infections in the age 70 to 79 years MoP group compared with MoM (10 of 451 [5\%] versus 29 of 628 [10\%]; OR, 4.47; CI, 1.699$11.761 ; \mathrm{p}=0.001)$. 
Conclusions There were high rates of dislocation, infection, and rerevision in both revision cohorts. The rate of dislocation was not greater after acetabular revision of MoM bearings at 2 years. Based on these findings, clinicians should counsel these patients preoperatively about the risks of these complications. Dual-mobility and constrained components have specific advantages and disadvantages in these settings and should be further studied.

Level of Evidence Level III, therapeutic study.

\section{Introduction}

Isolated revision of the acetabular component of THA may be performed for instability, wear, osteolysis, loosening, or infection in the presence of a well-fixed femoral component [25]. According to one study of the Medicare database, isolated revision of the acetabular component accounted for $13 \%$ of all revisions [4]. Isolated acetabular revision can be challenging and is associated with increased complications but has advantages of decreased blood loss and surgical time compared with both-component revisions [28, 35, 39]. Several studies have shown satisfactory results with isolated revision of the acetabular component in hips with metal-on-polyethylene (MoP) bearing surfaces using an uncemented porous-coated hemispherical shell $[9,11,15,19,25,31,34,35]$. However, the most common complication of isolated acetabular revision is dislocation, reported to be as high as 20\% [23].

Metal-on-metal (MoM) hip components were reintroduced to decrease the risks of early dislocation and late wear and osteolysis [27]. The rates of survival have been reported from $92 \%$ to $100 \%$ at 5 years and $82 \%$ to $100 \%$ at 10 years $[1,13,30,40]$. The most common indications for revision of MoM hips include adverse local tissue reaction (ALTR), aseptic loosening of the acetabular component, infection, and persistent groin pain [7]. Although many of these complications can occur with other bearing surfaces, ALTR related to particulate metal debris, molecular effects of metal ions, or corrosion products may contribute to extensive soft tissue destruction [36]. Some studies have suggested that the soft tissue damage associated with failure of the primary MoM hip components may also predispose to higher rates of complication after revision surgery, including dislocation and infection [32, 38, 42].

We therefore sought to answer the following questions in the context of a large database analysis: (1) Are there differences in the 30-day medical and wound complications after isolated acetabular revision of $\mathrm{MoM}$ and $\mathrm{MoP}$ components? (2) Are there differences in the frequency of dislocation, deep infection, and rerevision after isolated revision of the acetabular component based on the bearing surface of the initial implant?

\section{Patients and Methods}

We retrospectively queried the Medicare Standard Analytic Files database from 2005 to 2012 using PearlDiver Technologies (West Conshohocken, PA, USA). This searchable database contains $100 \%$ of both inpatient and outpatient claims with more than 50 million unique patient records including 1.1 million THAs. This research tool has been used in various studies in orthopaedic surgery $[14,24]$ and has been specifically validated for complications after total joint arthroplasty [2].

The proprietary coding language relies on International Classification of Diseases, 9th Revision, Clinical Modification (ICD-9-CM) and Current Procedural Terminology (CPT) codes, Boolean operators, and timeframe filters. The output values indicate the number of patients with a specified diagnosis or procedure within the stipulated time relationship to another specified diagnosis or procedure. If the output is a nonzero number less than 11 , rather than reporting a number, the program reports a “*” to prevent identification of a particular patient and comply with the Health Insurance Portability and Accountability Act. When this occurred in this study, the number was arbitrarily treated as a " 5 " (median between 1 and 10). This study was approved as exempt research by the Institutional Review Board for Clinical Investigations.

We conducted a search of the Medicare database to identify all patients undergoing THA (ICD-9-CM procedure code 81.51 or CPT code 27130) and separated them into two cohorts: those coded with a MoP bearing surface (ICD-9-CM procedure code 00.74) and those coded with a MoM THA (ICD-9-CM procedure code 00.75). Another study using Medicare inpatient claims from 2005 to 2007 used these codes to compare the rates of complications after primary THA among different bearing surfaces [6]. In the present study, codes were searched so as to exclude the same code being counted more than once for the same patient. We excluded patients with more than one hip replacement using the code count function for ICD-9-CM procedure code 81.51 and CPT code 27130 in addition to the ICD-9-CM diagnosis code V43.63 to ensure the capture of complications at an accurate time point from a population with only one primary THA with either MoM or MoP. The MoM and MoP cohorts were then each independently queried to identify those patients with a subsequent isolated acetabular revision code (ICD-9-CM procedure code 00.71 or CPT 27137). These bearing surface and isolated acetabular revision codes were introduced in 2005 and should be used when the acetabular component is revised 
whether or not the femoral head is revised [4]. For the specific surgical and medical complications, the cohorts were then filtered to exclude any patient whose isolated acetabular revision occurred in 2011 or 2012 to have at least 2-year followup for these patients.

Demographic information was obtained for both cohorts, including patient sex and age by group (younger than $65,65-$ $69,70-74,75-79,80-84,85$ years and older, and unknown). The number of patients with each Charlson Comorbidity Index (CCI) was also obtained with the mean, median, and SD. This information can be used to estimate 10-year mortality [8], and CCI has been validated in revision THA [37].

Both cohorts were also searched for specific medical complications using corresponding ICD-9 diagnosis and procedure codes occurring within the first 30 days from acetabular revision, including the same admission and all subsequent followup visits or readmissions. Similarly, patients in each cohort were crossreferenced for surgical complications within the first 30 days, 90 days, 1 year, and 2 years after acetabular revision. For the surgical complications, the acetabular revision admission was excluded from analysis because the preoperative indications for surgery could not be distinguished from any immediate postoperative complications. This rationale was applied to both the MoP and the MoM cohorts.

\section{Study Population}

Between 2005 and 2012, we identified 902 patients who had a THA with a MoM bearing who subsequently required an isolated revision of the acetabular component and 1159 patients with a MoP bearing surface THA and subsequently required isolated acetabular revision. Of these patients, 451 from the MoM and 628 from the MoP isolated acetabular revisions were performed before 2011 and could thus have a minimum followup of 2 years and are the subjects of this study. The patient demographics of these two groups of revisions were slightly different (Table 1).

\section{Statistical Analysis}

Data are presented using standard methods including the median and range for continuous variables (CCI) and counts with percentages for the categorical comorbidities and complications at each time point including odds ratios (ORs) with 95\% confidence intervals (CIs). Chi square methods were used to determine if each event rate was statistically different between the isolated acetabular revisions of MoM compared with MoP at each postoperative time point, whereas Fisher's exact test methods were used if any expected cell count was $<11$. As previously stated, if the output result was a "**," the value 5 was assigned as a best estimate (the center of the range). The main complications of interest (dislocation, infection and revision) were further stratified by age group and sex at 2 years postoperatively to determine if rates were different between MoM and MoP within each subgroup. Furthermore, the CochranMantel-Haenszel test was used to adjust for age and sex to determine if MoM and MoP revision complications were statistically different after adjusting for their influence as

Table 1. Patient demographics based on type of implant revised

\begin{tabular}{|c|c|c|c|c|c|c|c|}
\hline \multicolumn{8}{|l|}{ Characteristic } \\
\hline & \multicolumn{2}{|c|}{ Isolated acetabular revision of MoM } & \multicolumn{2}{|c|}{ Isolated acetabular revision of $\mathrm{MoP}$} & \multirow[t]{2}{*}{ OR } & \multirow[t]{2}{*}{$95 \% \mathrm{CI}$} & \multirow[t]{2}{*}{$\mathrm{p}$ value } \\
\hline Number of patients & 451 & & 628 & & & & \\
\hline \multicolumn{8}{|l|}{ Sex } \\
\hline Female & 277 & $61 \%$ & 417 & $66 \%$ & 0.83 & $0.64-1.07$ & 0.157 \\
\hline Male & 163 & $36 \%$ & 200 & $32 \%$ & 1.24 & $0.96-1.60$ & 0.100 \\
\hline \multicolumn{8}{|l|}{ Age (years) } \\
\hline Younger than 65 & 83 & $18 \%$ & 87 & $14 \%$ & 1.43 & $1.03-1.99$ & 0.033 \\
\hline $65-69$ & 87 & $19 \%$ & 87 & $14 \%$ & 1.51 & $1.09-2.10$ & 0.012 \\
\hline $70-74$ & 108 & $24 \%$ & 141 & $22 \%$ & 1.11 & $0.83-1.48$ & 0.483 \\
\hline $75-79$ & 96 & $21 \%$ & 141 & $22 \%$ & 0.95 & $0.71-1.28$ & 0.735 \\
\hline $80-84$ & 48 & $11 \%$ & 105 & $17 \%$ & 0.60 & $0.42-0.87$ & 0.006 \\
\hline 85 and older & 23 & $5 \%$ & 60 & $10 \%$ & 0.52 & $0.31-0.85$ & 0.008 \\
\hline \multicolumn{8}{|c|}{ Charlson Comorbidity Index } \\
\hline Median & 6 & & 6 & & & & \\
\hline SD & 4.17 & & 5.40 & & & & \\
\hline Range & $1-34$ & & $1-58$ & & & & \\
\hline
\end{tabular}

$\mathrm{MoM}=$ metal-on-metal; $\mathrm{MoP}=$ metal-on-polyethylene; $\mathrm{OR}=$ odds ratio; $\mathrm{CI}=$ confidence interval. 
well as to obtain adjusted ORs with $95 \%$ CIs. A p value < 0.05 was considered statistically significant. SAS Version 9.4 (SAS Institute, Cary, NC, USA) was used for all analyses.

\section{Results}

There were no differences between the cohorts in the 30day incidence of deep venous thrombosis, congestive heart failure, urinary tract infection, bleeding complications, postoperative anemia, or cellulitis. The proportion of patients receiving a transfusion (Table 2) was greater in the MoP group (37\% [250 of 672] with MoP and 31\% [147 of 474] with MoM; $\mathrm{p}=0.03$ ).

There were no differences in the frequency of dislocation, deep infection, or rerevision between the two cohorts at 30 days, 90 days, or 2 years (Table 3). At 1 year, there were more infections in the MoP cohort (27 of 451 [6\%]) compared with the MoM group (59 of 628 [9\%]; OR, 0.614; CI, 0.383-0.985; $\mathrm{p}=0.041$ ). Subgroup analysis showed that this occurred disproportionately in the age group 70 to 79 years (Table 4). The rate of infection differed between groups when stratified by age (Table 5).

The subgroup analysis for transfusion showed that the difference in transfusion rate was the result of a higher proportion of women in the MoP cohort and a higher rate of transfusion in woman compared with men (Table 4). The rate of transfusion differed by age and gender (Table 5).

Post hoc power analysis using the effect sizes at 2 years showed that this study is powered with $12.2 \%, 22.6 \%$, and $11.1 \%$ power for dislocation, infection, and rerevision, respectively. To achieve $80 \%$ power to detect a difference between the MoM and MoP revision, the cohorts would have to be 7000 for dislocation, 3000 for infection, and 8000 for rerevision.

\section{Discussion}

Isolated revision of the acetabular component often is performed for wear, osteolysis, and aseptic loosening in MoP bearing surface THAs, but varying rates of postoperative complications, including dislocation, have been reported [23]. Although early results were promising, MoM THA components have been reported in registry studies [16] to have higher rates of complication and failure associated with ALTR and muscle damage. It has been assumed that isolated acetabular revision of a failed MoM hip would have even higher rates of complications. However, there are several single-institution series of MoM revisions, not specifically focused on complications after acetabular revisions, but these are limited by small numbers of patients [32, 38, 42]. We asked the following questions: (1) Are there differences in the 30-day medical and wound complications after isolated acetabular revision of MoM and MoP components? (2) Are there differences in the frequency of dislocation, deep infection, and rerevision after isolated revision of the acetabular component based on the bearing surface of the initial implant?

We note several limitations to our study. First, it is an administrative database dependent on the accuracy of coding performed by administrative professionals who may be limited by the thoroughness of the medical documentation. Previous studies have found administrative claims to be useful in orthopaedic surgery [14, 24], and specifically in THA [3-5]. Bozic et al. [2] compared administrative claims data with institutional data and reported that it was highly specific $(>92 \%)$ for each arthroplasty-relevant complication and comorbidity tested but variable in their sensitivity (29\%-100\%). This level of accuracy may be sufficient for this study but also could influence the results, especially if documentation was more thorough for revisions of one bearing surface type compared with the other. Another previously mentioned administrative database

Table 2. Thirty-day complications after isolated acetabular revision of MoM and MoP components

\begin{tabular}{lcccc}
\hline Complication & MoM, number $(\%)$ & MoP, number $(\%)$ & OR & 95\% CI \\
\hline DVT & $14(3)$ & $24(4)$ & 0.806 & $0.412-1.576$ \\
Heart failure & $36(8)$ & $57(9)$ & 0.869 & $0.562-1.344$ \\
Urinary tract infection & $63(14)$ & $94(15)$ & 0.922 & $0.653-1.302$ \\
Bleeding complications & $20(4)$ & $29(5)$ & 0.958 & $0.535-1.717$ \\
Postoperative anemia & $165(37)$ & $218(35)$ & 1.085 & $0.843-1.397$ \\
Wound complications & $12(3)$ & $15(2)$ & 1.117 & $0.518-2.410$ \\
Cellulitis & $31(7)$ & $55(9)$ & 0.769 & $0.486-1.215$ \\
Transfusions & $134(30)$ & $230(37)$ & 0.731 & 0.528 \\
\hline
\end{tabular}

$\mathrm{MoM}=$ metal-on-metal; $\mathrm{MoP}=$ metal-on-polyethylene; $\mathrm{OR}=$ odds ratio $; \mathrm{CI}=$ confidence interval; $\mathrm{DVT}=$ deep vein thrombosis . 
Table 3. Dislocation, deep infection, and rerevision after isolated revision of MoM versus MoP acetabular components

\begin{tabular}{|c|c|c|c|c|c|c|}
\hline Complication & Time points & MoM, number (\%) & MoP, number $(\%)$ & OR & $95 \% \mathrm{CI}$ & $\mathrm{p}$ value \\
\hline \multirow[t]{4}{*}{ Dislocation } & 30 days & $16(4)$ & $23(4)$ & 0.968 & $0.505-1.853$ & 0.921 \\
\hline & 90 days & $27(6)$ & $32(5)$ & 1.186 & $0.700-2.009$ & 0.525 \\
\hline & 1 year & $63(14)$ & $95(15)$ & 0.911 & $0.646-1.285$ & 0.596 \\
\hline & 2 years & $73(16)$ & $113(19)$ & 0.880 & $0.637-1.216$ & 0.438 \\
\hline \multirow[t]{4}{*}{ Deep infection } & 30 days & $5^{*}(1)$ & $15(2)$ & 0.458 & $0.165-1.270$ & 0.124 \\
\hline & 90 days & $11(2)$ & $26(4)$ & 0.579 & $0.283-1.184$ & 0.130 \\
\hline & 1 year & $27(6)$ & $59(9)$ & 0.614 & $0.383-0.985$ & 0.041 \\
\hline & 2 years & $40(9)$ & $69(11)$ & 0.788 & $0.523-1.188$ & 0.255 \\
\hline \multirow[t]{4}{*}{ Rerevision } & 30 days & $11(2)$ & $18(3)$ & 0.847 & $0.396-1.812$ & 0.669 \\
\hline & 90 days & $16(4)$ & $29(5)$ & 0.760 & $0.408-1.416$ & 0.386 \\
\hline & 1 year & $58(13)$ & $94(15)$ & 0.838 & $0.589-1.192$ & 0.326 \\
\hline & 2 years & 77 (17) & 118 (19) & 0.890 & $0.648-1.221$ & 0.470 \\
\hline
\end{tabular}

* Number assumed to be 5 but could be any number between 1 and 10; MoM = metal-on-metal; MoP = metal-on-polyethylene; OR = odds ratio; $\mathrm{CI}=$ confidence interval.

Table 4. Dislocation, deep infection, rerevision, and transfusion of MoM versus MoP acetabular components by age and gender subgroups

\begin{tabular}{|c|c|c|c|c|c|c|}
\hline Complication & Subgroup & MoM, number $(\%)$ & $\begin{array}{l}\text { MoP, number } \\
\#(\%)\end{array}$ & OR & $95 \% \mathrm{CI}$ & $\mathrm{p}$ value \\
\hline \multirow[t]{5}{*}{ Dislocation } & Age $<69$ years & $34(20)$ & $42(24)$ & 1.273 & $0.763-2.123$ & 0.355 \\
\hline & Age $70-79$ years & $23(12)$ & $45(16)$ & 1.461 & $0.853-2.504$ & 0.166 \\
\hline & Age $>80$ years & $15(21)$ & $26(16)$ & 0.698 & $0.344-1.416$ & 0.318 \\
\hline & Female & $53(19)$ & $80(19)$ & 1.003 & $0.682-1.476$ & 0.987 \\
\hline & Male & $19(12)$ & $32(16)$ & 1.444 & $0.785-2.656$ & 0.236 \\
\hline \multirow[t]{5}{*}{ Deep infection } & Age $<69$ years & $22(13)$ & $28(16)$ & 1.290 & $0.706-2.359$ & 0.407 \\
\hline & Age $70-79$ years & $10 *(5)$ & $29(10)$ & 4.470 & $1.699-11.761$ & 0.001 \\
\hline & Age $>80$ years & $10 *(14)$ & $12(7)$ & 1.035 & $0.351-3.056$ & 0.950 \\
\hline & Female & $24(9)$ & $42(10)$ & 1.181 & $0.698-1.998$ & 0.536 \\
\hline & Male & $15(9)$ & 27 (14) & 1.540 & $0.789-3.004$ & 0.203 \\
\hline \multirow[t]{5}{*}{ Rerevision } & Age $<69$ years & $34(20)$ & $47(27)$ & 1.480 & $0.895-2.448$ & 0.125 \\
\hline & Age $70-79$ years & $29(15)$ & $46(16)$ & 1.149 & $0.694-1.904$ & 0.203 \\
\hline & Age $>80$ years & $11(15)$ & $25(15)$ & 0.974 & $0.451-2.106$ & 0.947 \\
\hline & Female & $56(20)$ & $89(21)$ & 1.071 & $0.736-1.559$ & 0.721 \\
\hline & Male & $18(11)$ & $29(15)$ & 1.366 & $0.729-2.561$ & 0.329 \\
\hline \multirow[t]{5}{*}{ Transfusion } & Age $<69$ years & $47(28)$ & $62(36)$ & 1.449 & $0.917-2.289$ & 0.111 \\
\hline & Age $70-79$ years & $56(28)$ & $102(36)$ & 1.457 & $0.984-2.158$ & 0.060 \\
\hline & Age $>80$ years & $27(38)$ & $63(38)$ & 1.007 & $0.568-1.785$ & 0.982 \\
\hline & Female & $85(31)$ & $169(41)$ & 1.539 & $1.116-2.123$ & 0.008 \\
\hline & Male & $44(27)$ & $57(28)$ & 1.078 & $0.679-1.712$ & 0.750 \\
\hline
\end{tabular}

* Exact value between 1 and 10 unknown; MoM = metal-on-metal; MoP = metal-on-polyethylene; OR = odds ratio; $\mathrm{CI}=$ confidence interval.

study comparing different bearing surfaces in primary THA acknowledged the important limitation and source of bias because bearing surface cohorts are defined by an optional modifier code [6]. The same limitation applies for this study of isolated acetabular revisions. Additionally, as a result of the limitations of the codes, it is not possible to differentiate between acetabular liner revisions and acetabular shell revisions. In the registry study of Lie et al. [26], both exchange of an acetabular component and a change of an acetabular liner were regarded as an acetabular revision. Second, although an administrative database is very useful for accumulating a large number of patients 
Table 5. Cochran-Mantel-Haenszel test stratified by age and sex for dislocation, infection, rerevision, and transfusion

\begin{tabular}{|c|c|c|c|c|c|}
\hline Event & Strata & $\begin{array}{l}\mathrm{CMH} \\
\mathrm{p} \text { value }\end{array}$ & OR & Lower CI & Upper CI \\
\hline Dislocation & Age & 0.310 & 1.18 & 0.85 & 1.64 \\
\hline Dislocation & Sex & 0.511 & 1.11 & 0.81 & 1.54 \\
\hline Infection & Age & 0.011 & 1.78 & 1.14 & 2.79 \\
\hline Infection & Sex & 0.201 & 1.31 & 0.86 & 1.98 \\
\hline Rerevision & Age & 0.192 & 1.24 & 0.90 & 1.71 \\
\hline Rerevision & Sex & 0.417 & 1.14 & 0.83 & 1.58 \\
\hline Transfusion & Age & 0.028 & 1.34 & 1.03 & 1.75 \\
\hline Transfusion & Sex & 0.019 & 1.37 & 1.05 & 1.78 \\
\hline
\end{tabular}

$\mathrm{CMH}=$ Cochran-Mantel-Haenszel; OR = odds ratio; $\mathrm{CI}=$ confidence interval.

Table 6. Isolated acetabular revision of metal-on-polyethylene bearing surfaces

\begin{tabular}{|c|c|c|c|c|c|c|}
\hline Study & $\begin{array}{l}\text { Number of hips } \\
\text { (patients) }\end{array}$ & $\begin{array}{l}\text { Followup: mean } \\
\text { (years; range) }\end{array}$ & Dislocation & $\begin{array}{l}\text { Aseptic cup } \\
\text { loosening }\end{array}$ & Deep Infection & $\begin{array}{l}\text { Survival rate (no rerevision } \\
\text { of acetabular component) }\end{array}$ \\
\hline $\begin{array}{l}\text { Poon and Lachiewicz } 1998 \\
\text { [35] }\end{array}$ & $38(36)$ & $4(2-10)$ & $3(8 \%)$ & $0 \%$ & 1 & $\begin{array}{l}100 \% \text { at final followup; } 95 \% \text { both } \\
\text { components }\end{array}$ \\
\hline Jamali et al. 2004 [22] & $\begin{array}{l}63(61) \\
95(93)\end{array}$ & $\begin{array}{l}10.8(5-17) \\
2\end{array}$ & $8 \%$ & $5 \%$ & 0 & $\begin{array}{l}90.5 \% \text { at } 10 \text { years; } 32 \text { additional } \\
\text { were included in survivorship } \\
\text { but not detailed analysis }\end{array}$ \\
\hline $\begin{array}{l}\text { Jones and Lachiewicz } 2004 \\
\text { [23] }\end{array}$ & $\begin{array}{l}69 \text { isolated acetabular } \\
\text { revision. } \\
142 \text { both component } \\
\text { revision }\end{array}$ & $6(<1-18)$ & $\begin{array}{l}14(20 \%) \\
11(8 \%)\end{array}$ & 4 of $211(2 \%)$ & 3 & $\begin{array}{l}95 \% \text { at } 12 \text { years; no statistically } \\
\text { significant difference between } \\
\text { isolated revision and both } \\
\text { component revision }\end{array}$ \\
\hline $\begin{array}{l}\text { Manning et al. } 2005 \text { [29] } \\
\text { (recalled components) }\end{array}$ & $26(25)$ & $2.4(2.1-2.7)$ & 0 & 0 & 0 & $100 \%$ at final followup \\
\hline Lawless et al. 2010 [25] & $42(39)$ & $6.4(2.5-13.4)$ & 0 & $3(7 \%)$ & $1(2 \%)$ & $\begin{array}{l}88 \% \text { at final followup includes } \\
\text { femur only revision for } \\
\text { fracture }\end{array}$ \\
\hline $\begin{array}{l}\text { Hernigou et al. } 2012 \text { [20] } \\
\text { (includes alumina) }\end{array}$ & $\begin{array}{l}165(150) \\
83 \text { alumina heads } \\
82 \text { metal heads }\end{array}$ & $\begin{array}{l}15(10-25) \\
15(10-20) \text { alumina } \\
\text { heads } \\
17(10-25) \text { metal } \\
\text { heads }\end{array}$ & 3 & $\begin{array}{l}2 \text { both in metal } \\
\text { heads }\end{array}$ & $\begin{array}{l}\text { NR ( } 0 \text { revisions for } \\
\text { infection) }\end{array}$ & $\begin{array}{l}100 \% \text { at } 10 \text { years and } 98 \% \text { at } 15 \\
\text { years alumina head; } 89 \% \text { and } \\
85 \% \text { at } 10 \text { and } 15 \text { years metal } \\
\text { head (survival rate for both } \\
\text { components) }\end{array}$ \\
\hline $\begin{array}{l}\text { Civinini et al. } 2012 \text { [10] } \\
\text { (dual mobility) }\end{array}$ & $33(33)$ & $3.3(2-5)$ & 0 & 0 & 1 & $97 \%$ at 5 years both components \\
\hline Wetters et al. 2013 [41] & $\begin{array}{l}316(\mathrm{NR}) \\
\text { out of } 1152 \text { (991) any type } \\
\quad \text { revision }\end{array}$ & $\begin{array}{l}2(0.25-7.1) \text { for all } \\
\text { revisions }\end{array}$ & $32(10 \%)$ & NR & NR & NR \\
\hline $\begin{array}{l}\text { Cogan et al. } 2011[11] \\
\text { (anterior approach) }\end{array}$ & $61(59)$ & $2.4(1-7)$ & $4(7 \%)$ & NR & NR & NR \\
\hline
\end{tabular}

$\mathrm{NR}=$ not reported.

with a specific diagnosis or operative procedure, it is limited in the level and type of information that can be provided compared with other types of studies. For example, the data in operative reports and radiographs, which would be used to determine the indication for revision, surgical approach, amount of bone loss [33], acetabular cup position, and soft tissue damage [7], are not available. In addition, the sizes of the removed and revision acetabular components, femoral heads, and retained femoral components are not available. The size of the femoral head component could be especially useful information for the risk of dislocation, because large femoral head components $(36-40 \mathrm{~mm})$ have been shown in two studies to reduce the risk of dislocation after revision THA $[17,21]$. Third, the acetabular revision admission was excluded from the analysis of dislocation, deep infection, and rerevision. The limitation of this approach is that any of these complications that occurred during that admission 
Table 7. Results after revision of metal-on-metal bearing surfaces

\begin{tabular}{|c|c|c|c|c|c|c|c|}
\hline Study & $\begin{array}{l}\text { Number } \\
\text { of hips } \\
\text { (patients) }\end{array}$ & $\begin{array}{l}\text { Mean } \\
\text { followup } \\
\text { (years; range) }\end{array}$ & Indication for revision & Dislocation & $\begin{array}{l}\text { Aseptic cup } \\
\text { loosening }\end{array}$ & Infection & Survival rate \\
\hline $\begin{array}{l}\text { Munro et al. } 2014 \text { [32]; } \\
\text { large-head MoM THA }\end{array}$ & $32(30)$ & $2.1(0.8-4)$ & $\begin{array}{l}19 \text { ALTR, } 3 \text { deep infection, } 10 \text { aseptic } \\
\text { loosening }\end{array}$ & $9(28 \%)$ & $\begin{array}{l}4 \text { of } 17 \text { titanium } \\
\text { components; } 0 \\
\text { tantalum }\end{array}$ & 0 & $81 \%$ at 2.1 years \\
\hline $\begin{array}{l}\text { Wyles et al. } 2014 \text { [42]; } \\
\text { THA }\end{array}$ & $37(37)$ & $2.75(2-6.75)$ & $\begin{array}{l}19 \text { aseptic loosening, } 8 \text { ALTR, } 4 \\
\text { periprosthetic fracture, } \\
3 \text { impingement, } \\
2 \text { dislocation, and } \\
1 \text { unknown origin }\end{array}$ & 0 & 0 & $3(8.1 \%)$ & $\begin{array}{l}95 \% \text { at } 2 \text { years; } 92 \% \\
\text { at last followup }\end{array}$ \\
\hline $\begin{array}{l}\text { Stryker et al. } 2015 \text { [38]; } \\
\text { monoblock THA }\end{array}$ & 114 (107) & $1.2(0-10.22)$ & $\begin{array}{l}58 \text { metallosis, } \\
31 \text { aseptic loosening, } 8 \text { infection, } 7 \\
\text { pain, } 5 \text { malposition, } 3 \text { instability, } 2 \\
\text { impingement, } 1 \text { periprosthetic } \\
\text { fracture }\end{array}$ & $4 \%$ & $6 \%$ & $6 \%$ & $84 \%$ at last followup \\
\hline $\begin{array}{l}\text { Schmolders et al. } 2011 \\
\text { [37]; } 12 \text { HRA, } 1 \text { THA }\end{array}$ & $13(13)$ & $1.75(1-3.33)$ & $\begin{array}{l}8 \text { groin pain, } 2 \text { lateral pain, } 3 \\
\text { dislocation or instability }\end{array}$ & 0 & NR & 0 & $\begin{array}{l}100 \% \text { at last } \\
\text { followup }\end{array}$ \\
\hline
\end{tabular}

MoM = metal-on-metal; HRA = hip resurfacing arthroplasty; ALTR = adverse local tissue reaction; NR = not reported.

would be excluded. However, if the index acetabular revision was not excluded, the rates would be dramatically overestimated, because all indications for the initial acetabular revision would also appear as complications of that surgery. Fourth, these findings are somewhat limited by relatively short-term followup after isolated revision of the acetabular component. The 8 years of available data in the Medicare database require a choice to be made between length of followup and size of the population with a given amount of followup. We excluded acetabular revisions performed in 2011 and 2012 to have minimum 2-year followup for major surgical complications. Fifth, for the rates of deep infection at 30 days and the age subgroups $<$ 69 years and 70 to 79 years in the MoM cohort, we assumed the number was five for previously stated reasons. This approximation was only used three times in our analyses. These limitations are important, but they are mitigated by the relatively large numbers of isolated revisions of the acetabular component of hips with MoM or MoP bearing surfaces included in the entire Medicare database. Other studies of isolated acetabular revisions have been single-institution reviews and included cohorts ranging from 26 to 165 patients [20,29]. However, the post hoc power analysis showed that this study is underpowered to detect small variations in effect size for the three major complications. Finally, this study cannot comment on the risk of complications of patients undergoing isolated acetabular revision who are not in the Medicare database. MoM hip arthroplasty was marketed to both a younger population to decrease wear complications and an older population to decrease dislocations. This study may have excluded many younger patients who would not be included in the Medicare database.
At the time of isolated acetabular revision, the cohorts with MoP and MoM bearing surfaces were very similar in terms of many demographic variables, comorbidities, and overall health as measured by the CCI. However, the MoM group had more male patients and a lower proportion of patients in the older age ranges. This may be the result of surgical selection bias in the mid-2000s with implantation of more MoM hips in younger male patients, because this bearing surface was anticipated to have less wear and osteolysis compared with MoP components [27]. This finding may also be related to increased failure of MoM hips in this subset of the Medicare patient population. A study by Lombardi et al. [27] of 1235 patients with a mean age of 58 years reported an increased risk of revision of large-diameter MoM THAs in younger patients. However, in that study, female patients were more likely to have failure of their MoM THA than male patients. Other studies have found that patient age did not affect patient outcome after THA revision surgery of any type [12] and isolated revision of the acetabular component specifically [25]. The identical mean and median CCI in our study shows that the two cohorts had the same 10-year predicted mean and median survival rates. However, the MoP cohort was larger and had a higher SD of CCI scores, indicating a wider distribution of preoperative health status and life expectancy compared with the MoM group.

Within the first 30 days after isolated acetabular revision, the rate of medical and wound complications was very similar between the two groups. Although bleeding complications and rates of postoperative anemia were not different between the two groups, one or more blood transfusions were more frequently administered to patients in the MoP cohort than the patients in the MoM cohort. 
This finding may be related to a higher proportion of female patients in this cohort, who may have had a lower preoperative hemoglobin concentration or who may have had a lower transfusion threshold. One study of the predictors of blood loss and transfusion requirements after revision THA found greater blood loss in men, elderly patients, and revisions of cemented (presumably polyethylene) components [28]. In that study after correction for confounding variables, only the preoperative hemoglobin concentration and the perioperative blood loss were associated with transfusion [28]. Patients undergoing isolated acetabular revision also had less blood loss and lower transfusion rates than both component revisions with $33 \%$ (21 of 63) of the patients undergoing isolated acetabular revision transfused at least one unit [28]. This was similar to the findings in our study.

The rates of dislocation after isolated acetabular revision have been reported from $0 \%$ to $20 \%$ at followups ranging from 2 to 15 years (Table 6). It was expected that, as a result of ALTR and soft tissue damage, the rate of dislocation after MoM isolated acetabular revision would be greater than MoP revision. In the present study, there were no differences in the rate of dislocation between the cohorts at any timeframe after isolated acetabular revision. The dislocation rate at 2 years was $19 \%$ for MoP and $16 \%$ for acetabular revisions of MoM. Both cohorts in this database have high rates of dislocation and may exceed the upper range of the published rates of dislocation. Contrary to what was expected, the MoM revision cohort did not dislocate at a higher rate. The timing of these dislocations was notable with $3 \%$ of the patients undergoing MoP isolated acetabular revision with a dislocation within the first 30 days and $15 \%$ within the first year. One study reported that most dislocations occurred early at a mean time of 3 days (range, 1-8 days) [20]. Other studies reported dislocation much later, more consistent with the present study [22, 41]. In an analysis of 113 hip dislocations after revision THA, the first dislocation occurred at median 77 days (range, 0 days to 4.9 years) [41]. One recent study reported no dislocations of 33 hips revised with the use of dual-mobility components [10]. The Swedish registry [18] reported only a $2 \%$ dislocation rate of 228 acetabular revisions using dual-mobility components. However, the administrative database used in the current study does not permit such a comparison, because there is no ICD-9 code specifically for dual-mobility or constrained components.

The rate of deep infection after revision of MoM components has been reported as high as $8 \%$ in a study of aseptic revisions with a mean followup of 33 months [42]. Deep infection after isolated acetabular revisions has been reported from $0 \%$ to $3 \%$ at 3- to 11-year followup [10, 22] (Table 6). Similarly, revisions of MoM have been reported to have high rates of infection, although these studies have not been specific to isolated acetabular revisions (Table 7). In the present study using the Medicare database, the rate of deep infection for MoP was $4 \%$ within the first 90 days and $11 \%$ at 2 -year followup. The isolated acetabular revisions of MoM components became infected $2 \%$ of the time within the first 90 days and $9 \%$ at 2 years. With the numbers available, we found no differences between MoM and $\mathrm{MoP}$ at any of the examined time points but were higher than other studies [10, 22, 23, 29, 32, 35, 38, 42]. These Medicare patients might have had more comorbidities and risk factors for infection than studies from single institutions.

In conclusion, the analysis of the Medicare database from 2005 to 2012 showed that there were high rates of complications after isolated revision of the acetabular component whether the bearing surface revised was either MoM or MoP. With the numbers available, there were no differences in the rates of dislocation, deep infection, or rerevision of acetabular revisions of MoM compared with MoP hips. Based on these findings, clinicians should counsel these patients preoperatively about the risks of these complications. The use of dual-mobility and constrained components has specific advantages and disadvantages in these settings. Further study of acetabular revisions with both bearing surfaces in national registries and multicenter studies should be performed. These studies could identify subgroups who would benefit from different approaches or component types to decrease complications after both types of isolated acetabular revisions.

Acknowledgments We thank the following people: Abiram Bala for helping develop the system by which the PearlDiver database was analyzed, Lindsay Kleeman for data analysis, Stephen Perlman for assistance with the literature review, Cindy Green for the statistical analyses, and Scott Ellison for answering questions about PearlDiver.

\section{References}

1. Bolland BJ, Culliford DJ, Langton DJ, Millington JP, Arden NK, Latham JM. High failure rates with a large-diameter hybrid metal-on-metal total hip replacement: clinical, radiological and retrieval analysis. J Bone Joint Surg Br. 2011;93:608-615.

2. Bozic KJ, Bashyal RK, Anthony SG, Chiu V, Shulman B, Rubash HE. Is administratively coded comorbidity and complication data in total joint arthroplasty valid? Clin Orthop Relat Res. 2013;471:201-205.

3. Bozic KJ, Kurtz S, Lau E, Ong K, Chiu V, Vail TP, Rubash HE, Berry DJ. The epidemiology of bearing surface usage in total hip arthroplasty in the United States. J Bone Joint Surg Am. 2009;91:1614-1620.

4. Bozic KJ, Kurtz SM, Lau E, Ong K, Vail TP, Berry DJ. The epidemiology of revision total hip arthroplasty in the United States. J Bone Joint Surg Am. 2009;91:128-133.

5. Bozic KJ, Lau EC, Ong KL, Vail TP, Rubash HE, Berry DJ. Comparative effectiveness of metal-on-metal and metal-onpolyethylene bearings in Medicare total hip arthroplasty patients. J Arthroplasty. 2012;27:37-40. 
6. Bozic KJ, Ong K, Lau E, Kurtz SM, Vail TP, Rubash HE, Berry DJ. Risk of complication and revision total hip arthroplasty among Medicare patients with different bearing surfaces. Clin Orthop Relat Res. 2010;468:2357-2362.

7. Browne JA, Bechtold CD, Berry DJ, Hanssen AD, Lewallen DG. Failed metal-on-metal hip arthroplasties: a spectrum of clinical presentations and operative findings. Clin Orthop Relat Res. 2010;468:2313-2320.

8. Charlson ME, Pompei P, Ales KL, MacKenzie CR. A new method of classifying prognostic comorbidity in longitudinal studies: development and validation. J Chronic Dis. 1987;40:373-383.

9. Cho HJ, Han SB, Park JH, Park SW. An analysis of stably fixed femoral components retained during revision total hip arthroplasty. J Arthroplasty. 2011;26:1239-1244.

10. Civinini R, Carulli C, Matassi F, Nistri L, Innocenti M. A dualmobility cup reduces risk of dislocation in isolated acetabular revisions. Clin Orthop Relat Res. 2012;470:3542-3548.

11. Cogan A, Klouche S, Mamoudy P, Sariali E. Total hip arthroplasty dislocation rate following isolated cup revision using Hueter's direct anterior approach on a fracture table. Orthop Traumatol Surg Res. 2011;97:501-505.

12. Davis AM, Agnidis Z, Badley E, Kiss A, Waddell JP, Gross AE. Predictors of functional outcome two years following revision hip arthroplasty. J Bone Joint Surg Am. 2006;88:685-691.

13. Delaunay CP, Bonnomet F, Clavert $\mathrm{P}$, Laffargue $\mathrm{P}$, Migaud $\mathrm{H}$. THA using metal-on-metal articulation in active patients younger than 50 years. Clin Orthop Relat Res. 2008;466:340-346.

14. Dhawan A, Mather RC 3rd, Karas V, Ellman MB, Young BB, Bach BR Jr, Cole BJ. An epidemiologic analysis of clinical practice guidelines for non-arthroplasty treatment of osteoarthritis of the knee. Arthroscopy. 2014;30:65-71.

15. Fukui K, Kaneuji A, Sugimori T, Ichiseki T, Kitamura K, Matsumoto T. Should the well-fixed, uncemented femoral components be revised during isolated acetabular revision? Arch Orthop Trauma Surg. 2011;131:481-485.

16. Furnes O, Paxton E, Cafri G, Graves S, Bordini B, Comfort T, Rivas MC, Banerjee S, Sedrakyan A. Distributed analysis of hip implants using six national and regional registries: comparing metal-on-metal with metal-on-highly cross-linked polyethylene bearings in cementless total hip arthroplasty in young patients. $J$ Bone Joint Surg Am. 2014;96(Suppl 1):25-33.

17. Garbuz DS, Masri BA, Duncan CP, Greidanus NV, Bohm ER, Petrak MJ, Della Valle CJ, Gross AE. The Frank Stinchfield Award: Dislocation in revision THA: do large heads (36 and 40 $\mathrm{mm})$ result in reduced dislocation rates in a randomized clinical trial? Clin Orthop Relat Res. 2012;470:351-356.

18. Hailer NP, Weiss RJ, Stark A, Karrholm J. Dual-mobility cups for revision due to instability are associated with a low rate of rerevisions due to dislocation: 228 patients from the Swedish Hip Arthroplasty Register. Acta Orthop. 2012;83:566-571.

19. He C, Feng JM, Yang QM, Wang Y, Liu ZH. Results of selective hip arthroplasty revision in isolated acetabular failure. J Surg Res. 2010;164:228-233.

20. Hernigou P, Dupuy N, Pidet O, Homma Y, Flouzat Lachaniette $\mathrm{CH}$. Alumina heads minimize wear and femoral osteolysis progression after isolated simple acetabular revision. Clin Orthop Relat Res. 2012;470:3094-3100.

21. Howie DW, Holubowycz OT, Middleton R. Large femoral heads decrease the incidence of dislocation after total hip arthroplasty: a randomized controlled trial. $J$ Bone Joint Surg Am. 2012;94:1095-1102.

22. Jamali AA, Dungy DS, Mark A, Schule S, Harris WH. Isolated acetabular revision with use of the Harris-Galante Cementless Component. Study with intermediate-term follow-up. J Bone Joint Surg Am. 2004;86:1690-1697.
23. Jones CP, Lachiewicz PF. Factors influencing the longer-term survival of uncemented acetabular components used in total hip revisions. J Bone Joint Surg Am. 2004;86:342-347.

24. Kelly MP, Savage JW, Bentzen SM, Hsu WK, Ellison SA, Anderson PA. Cancer risk from bone morphogenetic protein exposure in spinal arthrodesis. J Bone Joint Surg Am. 2014;96:1417-1422.

25. Lawless BM, Healy WL, Sharma S, Iorio R. Outcomes of isolated acetabular revision. Clin Orthop Relat Res. 2010;468:472-479.

26. Lie SA, Havelin LI, Furnes ON, Engesaeter LB, Vollset SE. Failure rates for 4762 revision total hip arthroplasties in the Norwegian Arthroplasty Register. J Bone Joint Surg Br. 2004;86:504-509.

27. Lombardi AV, Jr., Berend KR, Morris MJ, Adams JB, Sneller MA. Large-diameter metal-on-metal total hip arthroplasty: dislocation infrequent but survivorship poor. Clin Orthop Relat Res. 2015;473:509-520.

28. Mahadevan D, Challand C, Keenan J. Revision total hip replacement: predictors of blood loss, transfusion requirements, and length of hospitalisation. J Orthop Traumatol. 2010;11:159-165.

29. Manning DW, Ponce BA, Chiang PP, Harris WH, Burke DW. Isolated acetabular revision through the posterior approach: shortterm results after revision of a recalled acetabular component. $J$ Arthroplasty. 2005;20:723-729.

30. Mihalko WM, Wimmer MA, Pacione CA, Laurent MP, Murphy RF, Rider C. How have alternative bearings and modularity affected revision rates in total hip arthroplasty? Clin Orthop Relat Res. 2014;472:3747-3758.

31. Moskal JT, Danisa OA, Shaffrey CI. Isolated revision acetabuloplasty using a porous-coated cementless acetabular component without removal of a well-fixed femoral component. A 3- to 9year follow-up study. J Arthroplasty. 1997;12:719-727.

32. Munro JT, Masri BA, Duncan CP, Garbuz DS. High complication rate after revision of large-head metal-on-metal total hip arthroplasty. Clin Orthop Relat Res. 2014;472:523-528.

33. Paprosky WG, Perona PG, Lawrence JM. Acetabular defect classification and surgical reconstruction in revision arthroplasty. A 6-year follow-up evaluation. J Arthroplasty. 1994;9:33-44.

34. Park DK, Della Valle CJ, Quigley L, Moric M, Rosenberg AG, Galante JO. Revision of the acetabular component without cement. A concise follow-up, at twenty to twenty-four years, of a previous report. J Bone Joint Surg Am. 2009;91:350-355.

35. Poon ED, Lachiewicz PF. Results of isolated acetabular revisions: the fate of the unrevised femoral component. $J$ Arthroplasty. 1998;13:42-49.

36. Prieto HA, Berbari EF, Sierra RJ. Acute delayed infection: increased risk in failed metal on metal total hip arthroplasty. $J$ Arthroplasty. 2014;29:1808-1812.

37. Schmolders J, Friedrich MJ, Michel R, Strauss AC, Wimmer MD, Randau TM, Pennekamp PH, Wirtz DC, Gravius S. Validation of the Charlson comorbidity index in patients undergoing revision total hip arthroplasty. Int Orthop. 2015;39:1771-1777.

38. Stryker LS, Odum SM, Fehring TK, Springer BD. Revisions of monoblock metal-on-metal THAs have high early complication rates. Clin Orthop Relat Res. 2015;473:469-474.

39. Turner RH, Mattingly DA, Scheller A. Femoral revision total hip arthroplasty using a long-stem femoral component. Clinical and radiographic analysis. J Arthroplasty. 1987;2:247-258.

40. Vassan UT, Sharma S, Chowdary KP, Bhamra MS. Uncemented metal-on-metal acetabular component: follow-up of 112 hips for a minimum of 5 years. Acta Orthop. 2007;78:470-478.

41. Wetters NG, Murray TG, Moric M, Sporer SM, Paprosky WG, Della Valle CJ. Risk factors for dislocation after revision total hip arthroplasty. Clin Orthop Relat Res. 2013;471:410-416.

42. Wyles CC, Van Demark RE 3rd, Sierra RJ, Trousdale RT. High rate of infection after aseptic revision of failed metal-on-metal total hip arthroplasty. Clin Orthop Relat Res. 2014;472:509-516. 